Mohammad Gharipour and Nilay Özlü (eds.),

\title{
The City in the Muslim World: Depictions by Western Travel Writers, Culture and Civilization in the Middle East
}

Milton Park, Abingdon, Oxon: Routledge, 2015, 332 pp.,

ISBN 978-113-8842-62-5.

The question of space and place's relevance has slowly been gaining momentum in historiography for several years now. To an increasing extent, historians, especially those in the field of urban history, are asking questions inspired by their colleagues in geography and philosophy departments. The volume currently under review is an interesting addition to this body of work; yet it is also very much situated in the academic debate on Orientalism and 'Islamic cities'. As the editors rightfully indicate, much of this discussion has unfortunately ignored the urban locality of these cities. The editors aim to scrutinize the idea of the Islamic city through the lens of European travel writing, employing the term as a heuristic device to analyse how the cities of the 'Muslim world' were represented by travellers from Europe and America. Though it is obvious that employing terms such as 'Islamic city' and 'Muslim world' is problematic, the authors convincingly argue that the categories are vital both to understanding the context of European travel writing on 'the Muslim World' and further problematizing the idea of Orientalism as a homogeneous project of representing 'the West's' most significant 'Other'. The volume covers a broad array of geographies - from North Africa to the Indian subcontinent - through the lenses of travellers from Europe and the United States between the eleventh and twentieth century.

The book is subdivided in 12 essays which all include a number of illustrative pictures of reasonable quality. The first chapter, written by Mohammad Gharipour and Manu P. Sobti, provides an excellent account on tent cities in medieval travel writing. The authors analyse the duality of what they metaphorically, yet also quite literally, describe as the 'marriage between the tent and the palace'. They argue that the sedentarizing nomads made the conscious decision to incorporate the culture of the tent city in their urban surroundings, which had a notable and very visible effect on urban culture and space. The encampment functioned as a vessel of transference from a nomadic to a sedentary realm. One of the striking findings the authors present is the radical difference between the observations of local historians and travel writers. Contrary to the former, the travel writers from 
the western world considered nomadic elements as a mere curiosity in comparison to contemporary developments in Europe.

Felicity Ratté discusses in the second chapter the perceptions of Cairo by two fourteenth-century Italians, Niccolò da Poggibonsi and Leonardo di Niccolò Frescobaldi. The author analyzes written and visual material of these Italian travellers in order to comprehend how they understood their surroundings in Cairo. What is striking about this chapter is that it discusses the period that predates a 'common Orientalism' and concludes, based on the accounts of Niccolò and Leonardo, that rather than looking to distinctly 'othering' the city, the travellers are focusing on the elements in the urban landscape which make sense to them. The author argues that both of them give the impression that they felt a familiarity with the urban atmosphere of Cairo. As the author indicates, their sources provide an apt illustration of the level of cultural integration of societies around the Mediterranean. At no point do they refer to the city as fundamentally different from their own respective urban frame of reference.

The third chapter, by Mehreen Chida-Razvi, is centred around the question of how European travellers to Mughal cities represented the importance of these cities in their home countries. The Mughal court travelled along with the emperor between Delhi, Agra and Lahore, all three being imperial capitals. The author aims to bring attention to the apparent lack of discussion on Lahore in the travel accounts of European travellers, particularly in comparison to the accounts of their Mughal contemporaries. Three issues were presented as possible explanations: the asymmetry in the discussion of the urban landscape might be explained through the attention Europeans attached to the Lahore Fort, which they perceived as the representation of the emperor's political power. Secondly, Lahore was harder to frame as an Islamic city by the European travellers due to its heterogeneous religious and cultural reality. Another possible presented explanation is the travellers' intentions: they came to the Mughal Empire for attempts to convert locals, most notably the Mughal emperor. It would have been interesting and clarifying if the author had elaborated a bit further on the second and third argument, including a reflection on Agra and Delhi vis-à-vis Lahore.

Stefan Peychev in the fourth chapter discusses the descriptions by Western travellers of Sofia, with particular attention to its public baths and in comparison to Ottoman authors. Peychev tackles the Western perception of Sofia as an Oriental city, despite the fact that the city was in the European continent and its public 
baths were part of its urban landscape since Roman times. The baths functioned as an image, if not the city's image. Through four centuries, the author observes how European travellers 'othered' the city, though the process of representing the city as the 'other' evolved through history. Both on the local level and the level of the 'Islamic world' the author reveals how regional diversity and transformation challenges the understanding of categories such as 'Islamic world' and 'Islamic cities'.

In the fifth chapter Jørgen Mikkelsen analyses the expedition to the Islamic world - covering Egypt, the Levant, Anatolia, the Arabic peninsula, Persia and the West coast of the Indian subcontinent - by the Danish scholar Carsten Niebuhr between 1761 and 1767. The author argues that Niebuhr was an unusual person in the history of science due to his capacity to carefully describe localities and his 'remarkable empathy'. Niebuhr's strategy was to provide new findings to the existing knowledge on the Orient. Mikkelsen's main conclusion is that Niebuhr was an empiricist who did not align with his contemporaries who considered Arabs to be either people to be brought to the level of European civilization, or as 'noble savages' whose supposed positive traits were employed to criticize European societies. Niebuhr rather chose to perceive them as morally no better or worse than Europeans.

The author of the sixth chapter, Renia Paxinou, analyses the representation of Jannina in textual and pictorial sources - written accounts, maps, paintings and engravings - in the period of Ali Pasha's reign, i.e. 1788-1822. She describes how Western visitors perceived Jannina as the entrance to an exotic and uncivilized Orient. Pictorial and textual sources were produced to further substantiate ideas on what the Orient was, with Jannina featuring in the paradigm as an Oriental city, trapped between the mountains and ruled over by a despot. Within that context the author rightfully concludes that this is a challenging categorization; the Ottoman Balkans is a sub-category within both the Ottoman Empire and the 'Islamic world'. Jannina is even more problematic in that context as it had been and remained to be a predominantly Christian Greek city.

In chapter 7, Nilay Özlü investigates the changing representation of the Topkap1 Palace in Istanbul from the eighteenth to the twentieth century, based on the accounts of several European and American travellers. She reveals how the act of travelling and travellers themselves have evolved over time, coinciding with changing perceptions of the palace; from a bulwark of power and seclusion to a tourist spectacle. In one of the more theoretically engaging contributions of this volume she argues that the travellers were not only transferring the transformation 
of the palace's position in the empire and courtly culture, but also were active contributors in the process of place making for the Topkapı palace.

In Chapter 8, Valérie Géonet covers the chronological evolution of travellers' discourse on Arabs and Jews in Palestine, focusing on their perceptions of urban space. Through an analysis of 64 accounts written between 1799 and 1948, the author reaches the conclusion that there were mainly two representations of urban planning in Palestine. Christian towns were framed in a positive fashion, whereas Muslim towns were negatively framed between 1800 and 1917. From that period onward, incoming Europeans started to sympathize with Zionists and gave positive representations of their towns. Géonet argues that religious and ethnic backgrounds influenced the travellers' descriptions of the Palestine urban space. What was civilized and what was not was determined by the travellers' ethnocentrism, most of them from French descent. The idea of Western colonization was relayed from being a French effort to a European Zionist effort.

The volume continues with chapter 9 by Marie-Sofie Lundström who discusses the visual representation of the urban landscape by two Finnish painters. The author analyses how Hugo Backmansson and Oscar Parviainen painted Tunis as a stage to their pictorial representations of the 'Muslim city'. They employed strategies to transmit objectivity, i.e. signing with time and place, or painting specific elements of the 'Muslim' locale. The goal, however, was not to provide a truthful rendition of the Tunisian urban landscape, but rather a pictorial pastiche which could be sold as an appealing souvenir which would invoke a romantic and nostalgic longing for the past, described by Lundström as a response to the negative aspects of modernity.

Chapter 10 by M. Reza Shirazi investigates Tehran in the late nineteenth and early twentieth century through the lenses of European travel writers. The author argues that the consequence of the city's westernization was that it developed into a bipolar city in which the old city and the newly built quarters represented the typical Persian cityscape and a European one respectively. It provides an interesting case demonstrating the effects that Tehran's additional cityscape had on the representation of European travellers. Shirazi shows that the travellers concluded that there was a deep division in the city. The city's duality, represented as the 'old Orient' and the 'new Occident' in the old and new part of the city, made Tehran particularly interesting for European travellers and left a strong imprint on the way they described the city in their accounts.

Michelle H. Craig analyses the case of travel photographer Burton Holmes' narration of Fez through the lenses of his camera. Craig argues that Holmes 
upheld old Orientalist stereotypical representations on the Islamic city for Fez in order to appeal to American audiences. The chapter shows how Orientalism can be constructed by means of photography, in many ways similar to the way Orientalist representations have been used in texts. Holmes' work can be considered to attract interest to a romantic escapism while it can also be seen as a celebration of American modernity.

The final chapter by Davide Deriu discusses, in combination with reports from The Times newspaper, the views of four British travel writers, two from the 1920s and the other two between the late 1930s and early 1940s. Deriu convincingly shows how Ankara in the early republican era brought further disorder to already heterogenic representations of the Orient and Islamic cities. Although the author acknowledges the multiplicity of opinions in his sources, he does show that there is continuity in the argumentation on Ankara, particularly with regard to contrasting Old and New. More important according to Deriu is Atatürk, who appeared to be emblematic to the city's development. In conclusion, Deriu argues that the act of recognizing Ankara's modernism by the West in fact may well be perceived as an example of an enduring Orientalist tendency towards discursive colonization.

The editors have aimed to bring together essays which investigate the relation between individuals and their urban surroundings. A second common objective of of the editors and authors is to show how the Islamic city as a category is used by travellers. Finally, they aim to reveal how multi-dimensional and complex the travel literature is in general and in the context of travelling in the 'Muslim World' in particular. Although it seems - and it is - a daunting task to compile a volume which provides critical analysis on so many fronts, its authors have been successful at providing a cross section of geographies, temporalities and travellers' descent. A consequence of the volume's scope is that both the relation between the editors' theoretical framework and the contributions of some of the authors on the one hand and the coherence among the essays on the other may seem somewhat diffuse. Nevertheless, at large its scope is a significant merit and an impressive attempt to capture the multiplicity of travel writing on the urban spaces of the 'Muslim world'. On the practical side, the book's availability as an ebook is an advantage, especially considering the price of the volume's hardcover edition.

Enno Maessen University of Amsterdam 